\title{
Study of Subcutaneous Digital Tendon Rupture
}

\author{
by \\ Tomoko Higo, Akihiko Asami, Keisuke Nishida \\ and Hideo Watanabe \\ Department of Orthopaedic Surgery, \\ Saga Medical School, Saga, Japan \\ Takao Jinnai \\ Division of Plastic and Reconstructive Surgery, \\ Saga Medical School, Saga, Japan
}

Key words : subcutaneous tendon rupture, digital tendons, tendon suture, tendon transfer

\section{Introduction}

Subcutaneous digital tendon rupture is rare comparing with open tendon injury. In this series, the mechanism of injury, the method of sugery and the treatment results were investigated.

\section{Materials and methods}

Between October 1981 and August 1993, 25 fingers in 17 cases with subcutaneous digital tendon rupture treated at the Department of Orthopedic Surgery and the Division of Plastic and Reconstructive Surgery in Saga Medical School were investigated.

Six fingers in 6 cases were male and 19 fingers in 11 cases were famale. Their ages were ranging from 16 to 84 years (mean, 45.1).

The follow-up periods after the surgery were from 8 to 55 weeks (mean, 26 weeks).

\section{Results}

The involved tendons were 4 fingers in 4 cases of the extensor pollicis longus, 17 fingers in 9 cases of the extensor digitorum, 1 finger in 1 case of the flexor digitorum superficialis and 3 fingers in 3 cases of the flexor digitorum profundus.

The mechanisms of subcutaneous extensor tendon ruptures were bone fracture, hyperflexion of wrist and finger joint, crushing, rheumatoid arthritis and chronic inflammation. On the other hand, the subcutaneous rupture of flexor tendons were due to forced flexion injury and chronic inflammation (Table. 1).

All 17 cases in this series were right handed. The involved dominant hand was 21 fingers in 13 cases and the undominant hand was 4 fingers in 4 cases, respectively.

The incidence by zone classificasion of Kleinert ${ }^{5)}$ was 5 fingers in 5 cases for Zone 1,6 fingers in 1 case for Zone 6 and 10 fingers in 8 cases for Zone 7 in the extensor tendons, and 2 fingers in 1 case for Zone 2 and 2 fingers in 2 cases for Zone 4 in the flexor tendons, respectively.

The period of operation from the onset of rupture was from 3 days to 16 weeks (mean, 7.6 weeks) except 6 cases which the onset was not clear. 
Table. 1 Causes of extensor or flexor tendon repture.

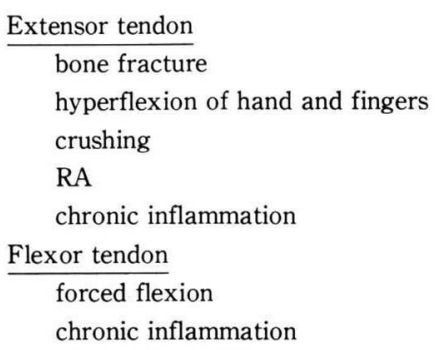

\author{
2 fingers in 2 cases \\ 4 fingers in 4 cases \\ 2 fingers in 2 cases \\ 7 fingers in 5 cases \\ 6 fingers in 1 case \\ 3 fingers in 2 cases \\ 1 finger in 1 case
}

All 17 cases were treated operatively. The tendon suture was perfomed in 9 fingers in 7 cases, and 12 fingers in 7 cases were treated with the tendon transfer in the extensor tendons rupture. In the cases of the flexor tendons rupture, the tendon suture was performed in 3 fingers in 3 cases.

According to the functional evaluation of tendon injury by the Japanese Society for Surgery of the Hand, 14 fingers in 7 cases were excellent and 7 fingers in 7 cases were good in extensor tendons rupture. Two fingers in 2 cases were excellent and 1 finger in 1 case was fair in flexor tendons rupture. There was no poor or worse cases nor reruptured case in both group.

\section{Case reports}

Case 1

A 56-year-old male, carpenter, had the histoty of sudden disability of flexion of his right little finger on March 3rd, 1992. He went to our associate hospital bacause of swelling and pain on the right palm after that.

Operation was performed on March 18th, 1992. The flexor digitorum profundus tendon of right little finger was ruptured and showed yellowish color and fraying of the ruptured end in the carpal tunnel region, and tendon suture was done at that time. Tenolysis was performed 3 months after the tendon suture in our hospital because of adhesion of the tendon, and the finger flexion was excellent

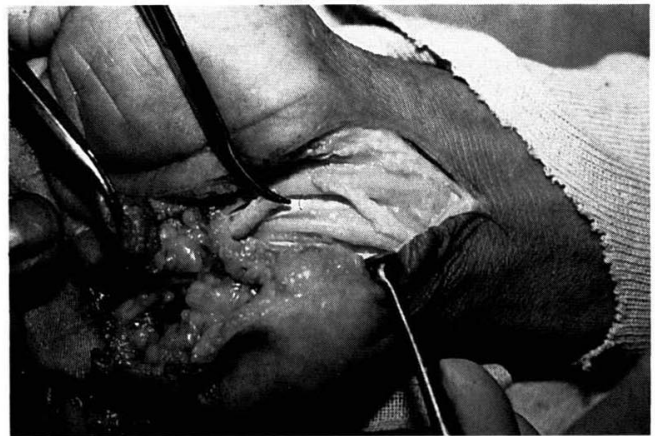

Fig. 1 Photogragh of case 1 shows a typical finding of flexor digitorum profundus tendon rupture in the right little finger. The tendon is frayed and attenuated in carpal tunnel.

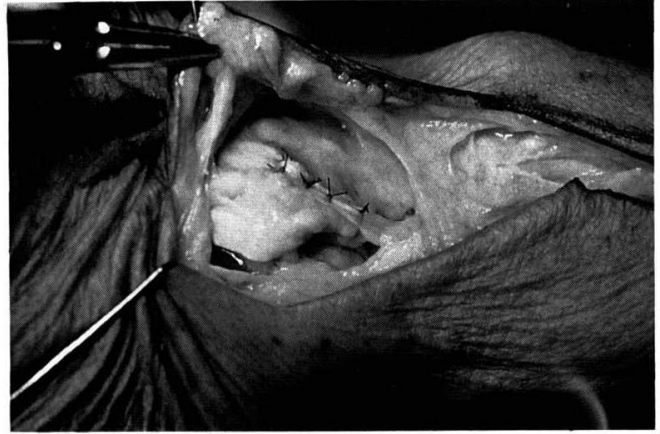

Fig. 2 The extensor carpi radialis brevis tendon was transfer to extensor digitorum tendon in the case 2 . 
postoperatively (Fig. 1)

Case 2

A 84-year-old female complaind of 3 months of extension disability of index, middie, ring and little fingers without obvious episode. she was referred to our hospital on October 16th, 1992. She was diagnosed as having subcutaneous tendon rupture of right extensor digitorum. On examination, the dorsal site of her right hand was swollen without pain and the head of ulna was subluxated dorsally.

Extensor carpi radialis brevis tendon was transfered to extensor digitorum tendon on November 24th, 1992 (Fig. 2). Active extension of fingers was restored well later.

\section{Discussion}

Subcutaneous tendon rupture of finger flexor is generally rare comparing with that of extensor. In this series, extensor tendon repture was 14 cases and flexor tendon rupture was only 3 cases.

Injured level of extensor tendon were mainly Zone 1 and Zone 7. Zone 1 injury included many young men's or women's mallet finger due to sprots. In Zone 7 injury, there were 2 cases of post lower end fracture of radius, 1 case of wrist hyperxtension and 7 cases of RA.

Extensor pollicis longus tendon rupture of post lower end fracture of radius are well-known. ${ }^{3(4) 7) 8)}$ There are mainly 2 causative theories; one is machinery factor theory due to bone fragment and another is avascular necrosis theory. ${ }^{4)}$ 7) Helal, B. et al. ${ }^{4)}$ stated that the difference in incidence between above two is due to the integrity of the extensor retinaculum in undisplaced Colles' type of fracture causing the tendon to be held tight against the fracture callus in the floor of the tunnel which may result in an attrition rupture. And in the displaced Colles' fracture the extensor retinaculum is torn from the bone and thus permits the tendon to escape from contact with the fracture site. Many authors mentioned that there is no rupture in the period of immobilization, and rupture of the tendon show a tendency to occur within 1 week after the removal of the cast. ${ }^{34)}$ So nutrition supply from synovial fluid to tendon may decrease among the period of casting.

In the case of operated RA patients, all showed subluxation of the head of ulna dorsally and the multiplication of synovium at the wrist joint. Tendon rupture in these patients may occur due to abrasion of the tendon and weakness by pannus invasion.

There are 2 main causes of rupture of flex or tendon; unexpected digital hyperextension and forced flexion against resistance. ${ }^{12)}$ In normal tendons, these ruptures will occur at either the tendon insertion on the musculotendinous junction, where tendons have been weakened by trauma or disease, rupture may occur within the tendon substance. ${ }^{12)}$

In our cases, both 2 cases were engaged in agriculture and carpentry for a long time. It seemed that tendon reptured were occured from forced flexion injury because the ruptured regions were anatomically weak points, such as the inserted region of lumbrical muscles and carpal tunnel.

The end of ruptured tendons in these group were usually swollen, ablated and faded away, so they were not suitable for surgical end-to-end suture, because the patients not always came to the hospital immidiately compare with clean cut injury.

It seems that the end-to-end suture is possible in the case of momentary rupture by strong stress, because intratendinous change was minimum within 4 weeks after the injury. ${ }^{6}{ }^{6}$ So we have tried to end-toend suture in these cases with comparative good condition in principle.

In the cases of extensor tendon reptures, treatment results were all excellent and good. But in the 
cases of flexor tendon ruptures, 1 case of Zone 2 rupture was fair, although other 2 cases were excellent. That is to say, the ruptured portion of the tendon seemed to play an important factor in flexor tendon rupture as well as open tendon injury.

\section{Conclusion}

1) Subcutaneous tendon rupture in the hand of 25 fingers in 17 cases were investigated.

2) End-to-end suture or tendon transfer were performed selectively.

3) All cases were resulted excellent or good, except one fair case which was ruptured at Zone 2 of flexor tendon.

\section{References}

1) Asai, M. et al. : Five cases of traumatic finger long flexor tendon subcutaneous rupture. J. Jpn. Soc. Surg. Hand., $4: 215-218,1987$.

2) Boyes, J. H., Wilson, J. N. and Smith, J, W. : Flexor-tendon ruptures in the forearm and hand. J. Bone and Joint Surg., 42-A : 637-646, 1960.

3) Fukuda, K. et al. : Spontaneous rupture of the extensor pollicis longus tendon. J. Jpn. Soc. Surg. Hand., $6: 513-518,1989$.

4) Helal, B., Chen, S. C. and Iwegbu, G : Rupture of the extensor pollicis longus tendon in undisplaced Colles' type of fracture. The Hand., $14: 41-47,1982$.

5) Kleinert, H. E. and Verdan, C. : Report of the comittee on tendon injuries. J. Hand Surg., $8: 794-798$, 1983.

6) Sakada, T., Yoshihara, M. and Ohmori, Y. : Histological findings of the ruptured ends of substaneous tendon rupture in the hand. J. Jpn. Soc. Surg. Hand., $5: 206-209,1988$.

7) Takami, H. et al. : Subcutaneous tendon ruptures in the hand. J. Jpn. Soc. Surg. Hand., $4: 212-214$, 1987.

8) Trevor, D. : Rupture of the extensor pollicis longus tendon after Colles' fracture. J. Bone and Joint Surg., 32-B : 370-375, 1950. 


\section{手指腱皮下断裂の検討}

$\begin{array}{lll}\text { 佐賀医科大学整形外科 } & \\ \text { 肥 後 知 子・浅 見 昭 彦 } \\ \text { 西 田 圭 介 - 渡 辺 英 夫 } \\ \text { 佐賀医科大学形成外科 } \\ \text { 陣 内 卓 雄 }\end{array}$

比較的まれな手指腱の皮下断裂について, 原因, 術 式，治療成績などを検討した。

対象は手指腱皮下断裂 17 例 25 指（男性 6 例 6 指, 女性 11 例 19 指，年齢 $16 \sim 84$ 歳，平均 45.1 歳）で, 術後経過観察期間は，8〜55 週，平均 26 週であった。 損偒腱の内訳は，長母指伸筋腱 4 例 4 指，指伸筋腱 9 例 17 指, 浅指屈筋腱 1 例 1 指, 深指屈筋腱 3 例 3 指 であった，原因は骨折，手指関節過屈曲，圧挫，RA， 慢性炎症, 屈曲位強制などで, 右側 13 例 21 指, 左側 4 例 4 指と左右差が認められた。
術式は伸筋腱断裂では腱縫合術 7 例 9 指, 腱移行術 7 例 12 指で，屈筋腱断裂では腱縫合術 3 例 3 指であっ た。

治療成績は伸筋腱断裂では excellent 7 例 14 指, good 7 例 7 指であり, 屈筋腱断裂では excellent 2 例 2 指, fair 1 例 1 指で, 再断裂は認められなかった。 断裂から手術までの期間が短く, 断端部の条件が比 較的良いものには腱縫合術を, そうでないものには腱 移行術を行い，良好な結果を得た。 